\title{
Effects of Mg Additions on Microstructure and Optical Properties of Sol-Gel Derived ZnO Thin Films
}

\author{
Chien-Yie Tsay ${ }^{1, *}$, Min-Chi Wang ${ }^{1}$ and Shin-Chuan Chiang ${ }^{2}$ \\ ${ }^{1}$ Department of Materials Science and Engineering, Feng Chia University, Taichung, Taiwan 40724, R.O.China \\ ${ }^{2}$ Taiwan TFT LCD Association (TTLA), Hsinchu, Taiwan 31040, R.O.China
}

Polycrystalline thin-films of $\mathrm{Zn}_{1-x} \mathrm{Mg}_{x} \mathrm{O}(0 \leq x \leq 0.36)$ have been prepared by a sol-gel method and a spin-coating technique. In this work, the authors investigate the effects of the $\mathrm{Mg}$ addition on crystallization, microstructure and optical properties for $\mathrm{ZnO}$ thin films. Mg was incorporated into $\mathrm{ZnO}$ thin films that were deposited onto glass substrates by a spin coating technique. The as-deposited films were preheated at $300^{\circ} \mathrm{C}$ for $10 \mathrm{~min}$ and then annealed at $500^{\circ} \mathrm{C}$ for $1 \mathrm{~h}$. The results show that addition of Mg-species in ZnO films markedly decreased surface roughness, improved transparency in the visible range and increased resistivity. Among the $\mathrm{Zn}_{1-x} \mathrm{Mg}_{x} \mathrm{O}$ films investigated in the present study, the $\mathrm{Zn}_{0.8} \mathrm{Mg}_{0.2} \mathrm{O}$ thin film exhibited the best properties, namely single wurzite phase, an optical transmittance of $94.7 \%$, an RMS roughness of $1.63 \mathrm{~nm}$ and a resistivity of $8.3 \times 10^{5} \Omega-\mathrm{cm}$. [doi:10.2320/matertrans.MER2007334]

(Received December 21, 2007; Accepted February 26, 2008; Published April 16, 2008)

Keywords: $\mathrm{ZnO}, \mathrm{Zn}_{1-x} \mathrm{Mg}_{x} \mathrm{O}$ thin films, optical properties, sol-gel method

\section{Introduction}

Wide bandgap $(>3 \mathrm{eV})$ transparent conductive oxides (TCO), such as zinc oxide $(\mathrm{ZnO})$, tin oxide $\left(\mathrm{SnO}_{2}\right)$ and indium tin oxide (ITO), have been extensively used to make environmentally sustainable energy components and opticalelectrical systems. ${ }^{1)}$ Among these materials, $\mathrm{ZnO}$ prepared at low temperatures has properties including non-toxicity, high transparency, and high crystallinity. It has become a promising candidate for novel device applications, such as transparent electronics ${ }^{2)}$ and flexible displays. ${ }^{3)}$ Owing to its unique electrical and optical properties, it has been popularly used in varistors, chemical sensors, piezoelectric devices, etc. Recently, $\mathrm{ZnO}$ thin films have attracted interest for solar cell and flat panel display (FPD) applications, such as window layers for thin film solar cells, ${ }^{4)}$ transparent conductive layers for touch panels ${ }^{5)}$ and active channel layers for thin-film transistors (TFTs). ${ }^{6)}$

$\mathrm{ZnO}$ is an n-type oxide semiconductor material with a direct wide bandgap of $3.35 \mathrm{eV}$. Its electrical characteristics can be controlled by doping or by incorporating ternary elements, ${ }^{7,8)}$ such as $\mathrm{Al}, \mathrm{In}, \mathrm{Ga}$ etc. The carrier mobility of pure $\mathrm{ZnO}$ exceeds the field effect mobility of hydrogenated amorphous silicon (a-Si:H), which serves as an active channel layer material in typical TFT arrays. In addition, polycrystalline $\mathrm{ZnO}$ films can be prepared in a normal atmosphere. Because $\mathrm{ZnO}$-based materials may replace amorphous silicon for active layer applications, this subject presently attracts much attention.

The solution-based process offers a simple and low cost thin film deposition method as an alternative to vacuum deposition techniques (PVD or CVD). Oxide semiconductor formed from the solution process may improve the manufacturing throughput of microelectrical devices by enabling maskless processes, including inkjet printing and selective electroless plating, etc. ${ }^{9)}$ The sol-gel method is one of

*Corresponding author, E-mail: cytsay@fcu.edu.tw common solution processes that is popularly used for polycrystalline oxide thin film deposition. ${ }^{10,11)} \mathrm{ZnO}$-based semiconductor films have been shown to be suitable for service as TFT active channel layers. ${ }^{12-15)}$ Kwon et al. ${ }^{16)}$ indicated that to control the carrier density of the active layer in a $\mathrm{ZnO}$-based TFT is a challenge, because the active layer supplies high carrier density that will be conducting when an applied gate voltage is absent. The ionic radius of $\mathrm{Mg}^{2+}$ $(0.065 \mathrm{~nm})$ is smaller than $\mathrm{Zn}^{2+}(0.074 \mathrm{~nm})$, and thus the solid solubility limit of $\mathrm{MgO}$ in $\mathrm{ZnO}$ can approach 40 at\%. ${ }^{17,18)}$ The incorporation of $\mathrm{Mg}$ into $\mathrm{ZnO}$ films tends to decrease the interstitial oxygen vacancies ${ }^{19)}$ and electron density. ${ }^{20)}$ Many reports have demonstrated that the solubility limit of $\mathrm{Mg}$ content in $\mathrm{Zn}_{1-x} \mathrm{Mg}_{x} \mathrm{O}$ films strongly depends on deposition or growth technique, e.g. PLD, ${ }^{18,21)}$ sputtering, ${ }^{22)}$ MOVPE, ${ }^{17)}$ and sol-gel method. ${ }^{23,24)}$

In the present study, polycrystalline $\mathrm{Zn}_{1-x} \mathrm{Mg}_{x} \mathrm{O}$ thin films were fabricated by a sol-gel method and a spin coating technique; the effects of $\mathrm{Mg}$ additions on crystallinity, microstructure, and optical properties were investigated. Moreover, these thin films' electrical characteristics were tested to determine whether these films could serve as TFTs active channel layers.

\section{Experimental}

To synthesize $\mathrm{Zn}_{1-x} \mathrm{Mg}_{x} \mathrm{O}$ sols, $\mathrm{Mg}^{2+}$ was varied from 0 to 0.36 (for $x$ values); a mixture of zinc acetate dehydrate $\left(\mathrm{Zn}\left(\mathrm{CH}_{3} \mathrm{COO}\right)_{2} \cdot 2 \mathrm{H}_{2} \mathrm{O}\right)$ and magnesium acetate tetra-hydrate $\left(\mathrm{Mg}\left(\mathrm{CH}_{3} \mathrm{COO}\right)_{2} \cdot 4 \mathrm{H}_{2} \mathrm{O}\right)$ was dissolved in a solution of 2methoxyethanol and monoethanolamine (MEA). The molar ratio of MEA to metal ions in each $\mathrm{Zn}_{1-x} \mathrm{Mg}_{x} \mathrm{O}$ sol was maintained at 1.0 and each concentration of metal ions was controlled at $0.75 \mathrm{~mol} / \mathrm{L}$. The complex solution was stirred for $2 \mathrm{~h}$ at $60^{\circ} \mathrm{C}$ until a clear, homogenous and stable sol was obtained. All $\mathrm{Zn}_{1-x} \mathrm{Mg}_{x} \mathrm{O}$ gel films were coated onto alkalifree glass (Corning 1737, with dimension $5 \times 5 \mathrm{~cm}^{2}$ ) using spin coating at a speed of $3000 \mathrm{rpm}$ for 30 seconds. The as- 
Table 1 Average crystallite size, surface roughness, visible transmittance, optical bandgap and resistivity obtained for $\mathrm{Zn}_{1-x} \mathrm{Mg}_{x} \mathrm{O}$ thin films.

\begin{tabular}{|c|c|c|c|c|c|c|}
\hline$x$ in $\mathrm{Zn}_{1-x} \mathrm{Mg}_{x} \mathrm{O}$ & 0 & 0.1 & 0.2 & 0.3 & 0.33 & 0.36 \\
\hline Average crystallite size (nm) & 8.9 & 8.8 & 8.7 & 8.4 & 8.5 & 8.4 \\
\hline RMS roughness $(\mathrm{nm})$ & 16.24 & 7.81 & 1.63 & 1.97 & 2.79 & 3.82 \\
\hline Optical bandgap (eV) & 3.24 & 3.36 & 3.51 & 3.52 & 3.47 & 3.47 \\
\hline Resistivity $(\Omega-\mathrm{cm})$ & $2.5 \times 10^{3}$ & $2.7 \times 10^{4}$ & $8.3 \times 10^{5}$ & $6.4 \times 10^{4}$ & $3.5 \times 10^{4}$ & $2.5 \times 10^{4}$ \\
\hline
\end{tabular}

*Only transmittances at a wavelength of $550 \mathrm{~nm}$ were presented in this table.

coated films were preheated at $300^{\circ} \mathrm{C}$ for 10 mins immediately after coating. After repeating the coating procedure three times, the films were annealed in a tube furnace at $500^{\circ} \mathrm{C}$ for $1 \mathrm{~h}$ in air.

After the annealing step, X-ray diffractometry (XRD, MAC Science MXP3, Japan) was used to examine the crystallinity levels of the pure $\mathrm{ZnO}$ and $\mathrm{Mg}$ incorporated $\mathrm{ZnO}$ thin films. The surface morphology and microstructure of each $\mathrm{Zn}_{1-x} \mathrm{Mg}_{x} \mathrm{O}$ film were observed by scanning electron microscopy (SEM, HITACHI S-4800, Japan). A scanning probe microscope (SPM, Digital Instrument NS4/D3100CL, Germany) was used to analyze the surface roughness levels of the films. The resistivities were measured by a high resistivity meter (MCP-HT450, DIA INSTRUMENTS CO., LTD, Japan). Moreover, optical transmittance spectra of these films were examined by a spectrophotometer (MiniD2T, Ocean Optics Inc., USA).

In this study, $\mathrm{Zn}_{1-x} \mathrm{Mg}_{x} \mathrm{O}$ films served as the active channel layers of TFTs. Figure 6(a) shows a schematic diagram of a TFT with a $\mathrm{Zn}_{1-x} \mathrm{Mg}_{x} \mathrm{O}$ active layer. The simple bottom-gate structure devices were fabricated by a hybrid method that combined the standard micro-electrical fabrication process and a solution-based process. Spin coating finished each $\mathrm{Zn}_{1-x} \mathrm{Mg}_{x} \mathrm{O}$ TFT by depositing a $\mathrm{Zn}_{1-x} \mathrm{Mg}_{x} \mathrm{O}$ thin film onto the multilayer $\mathrm{MoW} / \mathrm{SiO}_{2} / \mathrm{ITO}$ structure. The $I_{D}-V_{D}$ characteristics of the transistors with $\mathrm{Zn}_{1-x} \mathrm{Mg}_{x} \mathrm{O}$ active channel layers were measured in a dark room using a semiconductor parameter analyzer (HP 4155B, USA).

\section{Results and Discussion}

Figure 1 presents XRD patterns of pure $\mathrm{ZnO}$ and $\mathrm{Zn}_{0.8} \mathrm{Mg}_{0.2} \mathrm{O}$ thin films. Two patterns correspond to three main diffraction peaks of the $\mathrm{ZnO}$ : (100), (002) and (101). All $\mathrm{Zn}_{1-x} \mathrm{Mg}_{x} \mathrm{O}(x=0-0.36)$ gel films were preheated at $300^{\circ} \mathrm{C}$ and then annealed at $500^{\circ} \mathrm{C}$, producing polycrystalline films with hexagonal wurzite structure (Zincite, JCPDS 36-1451). X-ray diffractographs of $\mathrm{Zn}_{1-x} \mathrm{Mg}_{x} \mathrm{O}$ films show that the intensity of diffraction peaks decrease with increasing $\mathrm{Mg}$ content, viz. $\mathrm{Mg}$ incorporated within $\mathrm{ZnO}$ films caused the crystallinity to degenerate. The $\mathrm{Zn}_{0.8} \mathrm{Mg}_{0.2} \mathrm{O}$ film shows a highly $c$-axis oriented (002) peak (curve (b) in Fig. 1). To estimate the average crystallite size $(d)$ of these samples, Scherrer's formula ${ }^{25)}$ is used;

$$
d=\frac{0.9 \lambda}{B \cos \theta_{B}}
$$

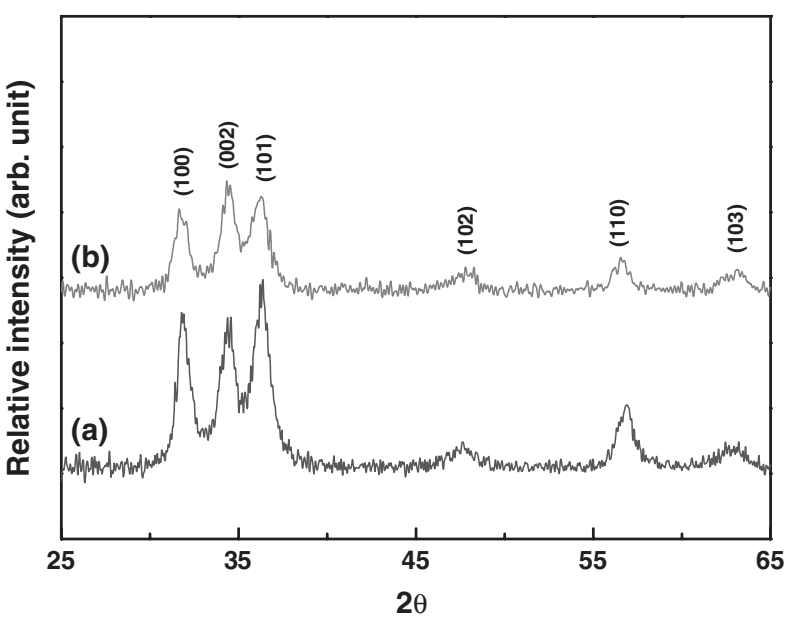

Fig. 1 XRD patterns of (a) $\mathrm{ZnO}$ and (b) $\mathrm{Zn}_{0.8} \mathrm{Mg}_{0.2} \mathrm{O}$ thin films annealed at $500^{\circ} \mathrm{C}$ for $1 \mathrm{~h}$.

where $\lambda$ is the X-ray wavelength of $0.154 \mathrm{~nm}, \theta_{B}$ is the Bragg diffraction angle and $B$ is the FWHM (full width at half maximum) of $\theta_{B}$. The calculated average crystallite size of $\mathrm{Zn}_{1-x} \mathrm{Mg}_{x} \mathrm{O}$ films are summarized in Table 1 that shows $\mathrm{Mg}$ incorporated $\mathrm{ZnO}$ thin films have slightly reduced average grain size. The experimental results also show that when the $\mathrm{Mg}$ content is more than $30 \mathrm{at} \%$, the $\mathrm{MgO}$ phase becomes segregated. In previous reports, the high solubility of $\mathrm{Mg}$ ions in $\mathrm{ZnO}$ films were demonstrated. For example, Ohtomo et $a l .{ }^{26)}$ reported the soluble range of epitaxial $\mathrm{Zn}_{1-x} \mathrm{Mg}_{x} \mathrm{O}$ films was from 0.25 to 0.33 in films that were grown by PLD. Also, Zhao et al. ${ }^{23)}$ demonstrated that when the $\mathrm{Mg}$ content exceeded 0.36, the $\mathrm{MgO}$ phase segregation would occur at $800^{\circ} \mathrm{C}$. In their study, the $\mathrm{Zn}_{1-x} \mathrm{Mg}_{x} \mathrm{O}$ films were fabricated by sol-gel method.

After $\mathrm{Mg}$ incorporation, slight shifts are observed in the (002) and (001) peaks. The lattice parameters of $a$ - and $c$-axes were calculated using $a=\lambda / \sqrt{3} \sin \theta$ and $c=$ $\lambda / \sin \theta$, respectively. Figure 2(a) shows the two lattice parameters as a function of $\mathrm{Mg}$ content. Results indicate that $\mathrm{Mg}^{2+}$ substituted for $\mathrm{Zn}^{2+}$ can increase the $a$-axis length from 0.3224 to $0.3240 \mathrm{~nm}$ and decrease $c$-axis length from 0.5195 to $0.5167 \mathrm{~nm}$, when the $x$-value is below 0.3 . It may be the case that $\mathrm{Mg}$ substitution increases the strain in the lattice. ${ }^{27)}$ In films with up to $\sim 33$ at $\% \mathrm{Mg}$ incorporation, the lattice parameters that changed were opposite to the parameters that changed in single-phase samples. Figure 2(b) shows $\mathrm{Mg}$ incorporated into $\mathrm{ZnO}$ thin films have slightly increased the cell volume. 


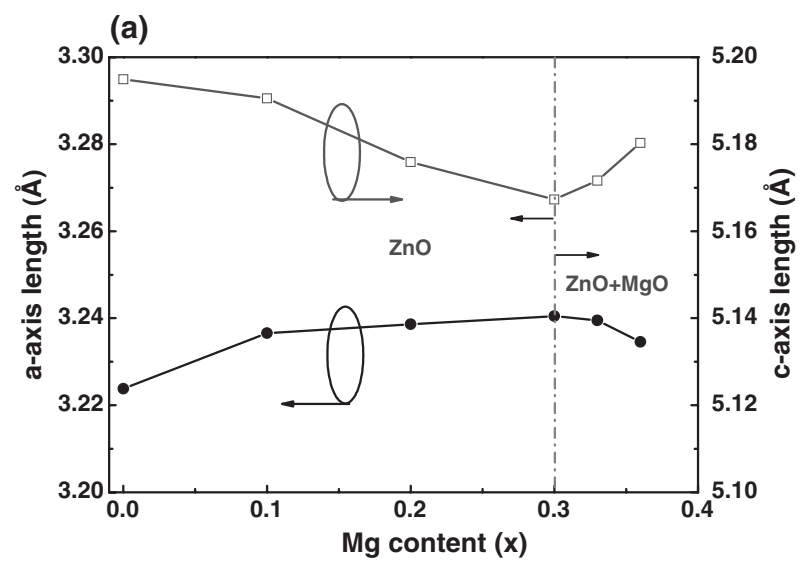

(b)

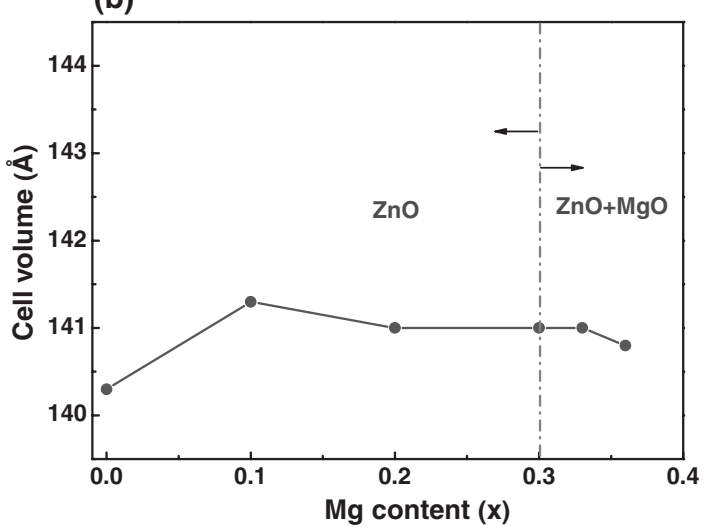

Fig. 2 (a) The $a$ - and $c$-axis lattice parameters and (b) the cell volume of $\mathrm{Zn}_{1-x} \mathrm{Mg}_{x} \mathrm{O}$ thin films as a function of $\mathrm{Mg}$ content.
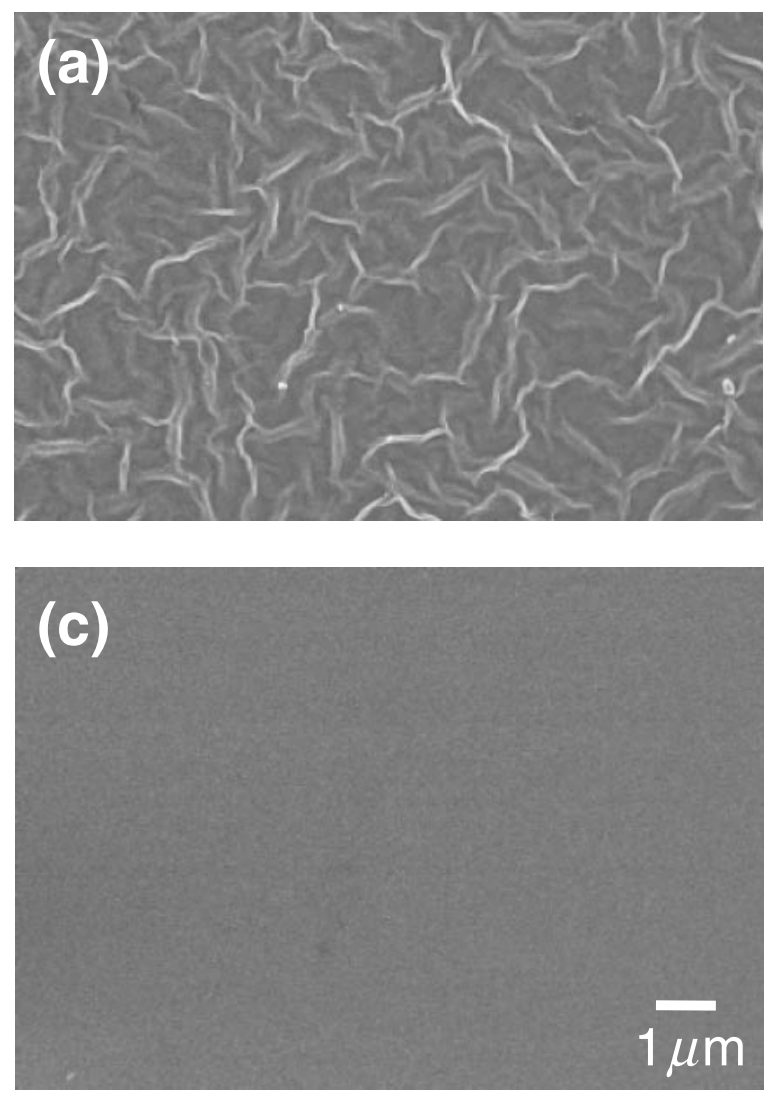

Spin coating is a simple oxide thin film deposition technique, but it requires soluble types of reagents. It is possible to control the film thickness by merely adjusting the solution viscosity or coating times. The plane view of an SEM image of an annealed pure $\mathrm{ZnO}$ film shows fiber-like streaks or wrinkles (Fig. 3(a)). However, the incorporated samples do not display that appearance, as can be seen from the surface image of $\mathrm{Zn}_{0.8} \mathrm{Mg}_{0.2} \mathrm{O}$ film (Fig. 3(c)). According to a previous report, ${ }^{28)}$ the fiber-like streaks or wrinkles are induced by the shortness of $\mathrm{OH}$ and $\mathrm{OR}$ groups. Magnesium acetate tetrahydrate is a source for $\mathrm{Mg}$ ions, and thus can provide enough $\mathrm{OH}$ groups. Thus, a relatively smooth surface can be obtained for $\mathrm{Zn}_{1-x} \mathrm{Mg}_{x} \mathrm{O}$ thin films. Cross-sectional SEM images of the $\mathrm{ZnO}$ and $\mathrm{Zn}_{0.8} \mathrm{Mg}_{0.2} \mathrm{O}$ thin films are shown in Figs. 3(b) and 3(d), respectively. Figure 3(b) is an SEM micrograph of the $\mathrm{ZnO}$ film that shows its average thickness is about $140 \mathrm{~nm}$. Figure 3(d) shows that the average thickness of incorporated films is about $150 \mathrm{~nm}$ and addition of $\mathrm{Mg}$-species to the $\mathrm{ZnO}$ films markedly improved the surface flatness and enhanced the uniformity of film thickness. This SEM image (Fig. 3(d)) also reveals that $\mathrm{Mg}$ incorporation in $\mathrm{ZnO}$ films can reduce the average crystallite size; XRD measurements confirm this finding.

When $\mathrm{Mg}$ incorporates with a $\mathrm{ZnO}$ thin film, it influences the surface morphology. It is apparent that $\mathrm{Mg}$ substitution in $\mathrm{ZnO}$ film causes a decrease in average crystallite size, which in turn causes a reduction of surface roughness. Table 1 presents the values of RMS roughness of $Z_{1-x} \mathrm{Mg}_{x} \mathrm{O}$ thin films, and shows that $\mathrm{Mg}$ incorporation yields a significant improvement of surface roughness. Figure 4 shows the
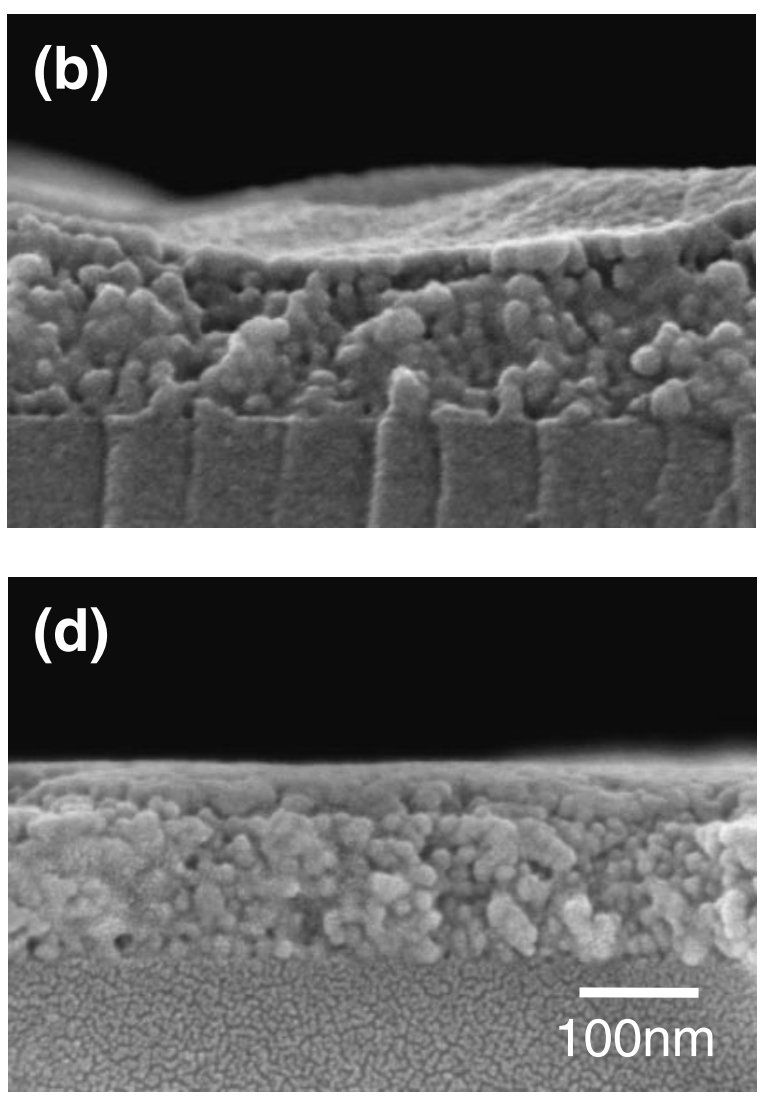

Fig. 3 SEM images of plane view and cross-section of $\mathrm{Zn}_{1-x} \mathrm{Mg}_{x} \mathrm{O}$ thin films: (a), (b) $x=0$ and (c), (d) $x=0.2$. 


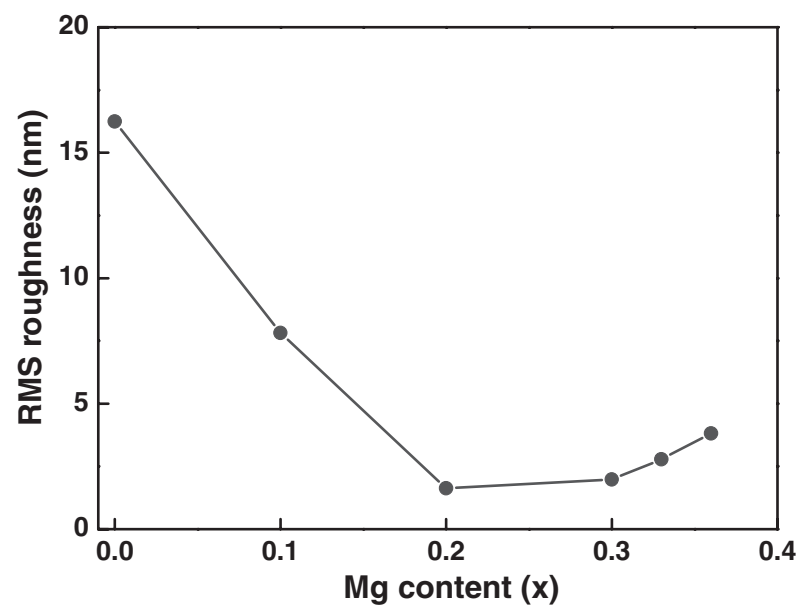

Fig. 4 Surface roughness of $\mathrm{Zn}_{1-x} \mathrm{Mg}_{x} \mathrm{O}$ thin films as a function of $\mathrm{Mg}$ content.
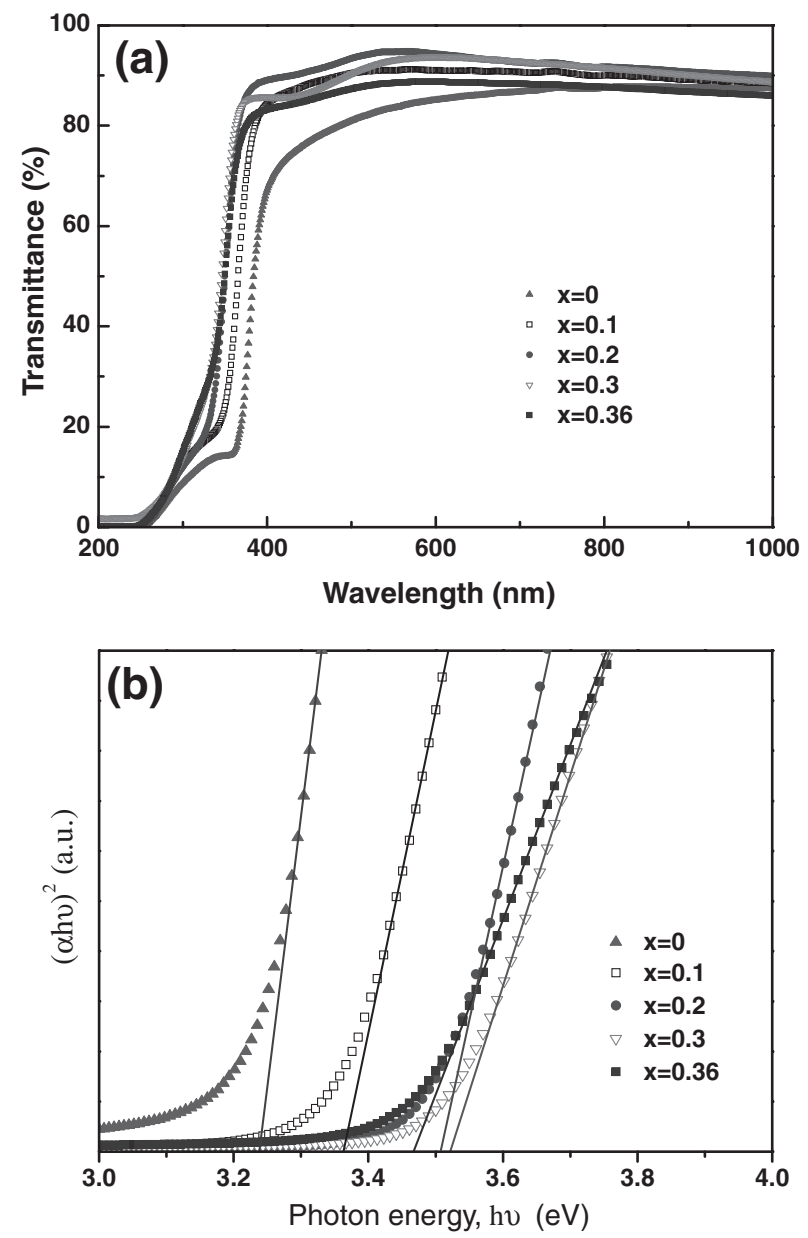

Fig. 5 (a) Optical transmittance spectra and (b) plot of $(\alpha h v)^{2}$ vs. photon energy of pure $\mathrm{ZnO}$ and $\mathrm{Mg}$ incorporated $\mathrm{ZnO}$ thin films.

relationship of RMS roughness to $\mathrm{Mg}$ concentration; as $\mathrm{Mg}$ concentration increased from 0.0 to 0.2 , RMS roughness decreased, but greater $\mathrm{Mg}$ concentrations increased roughness. That is, among all of the annealed $\mathrm{Zn}_{1-x} \mathrm{Mg}_{x} \mathrm{O}$ thin films in this study, the $\mathrm{Zn}_{0.8} \mathrm{Mg}_{0.2} \mathrm{O}$ thin film exhibited the smallest RMS value, namely $1.63 \mathrm{~nm}$.

Figure 5(a) shows the optical transmittance spectra of the
$\mathrm{Zn}_{1-x} \mathrm{Mg}_{x} \mathrm{O}$ thin films examined at room temperature. All samples showed sharp absorption edges in the UV region and these absorption edges shifted to shorter wavelengths when the $\mathrm{ZnO}$ thin films were augmented with $\mathrm{Mg}$. A previous study reported that the absorption maxima of $\mathrm{Zn}_{1-x} \mathrm{Mg}_{x} \mathrm{O}$ films blueshifted as a function of the $\mathrm{Mg}$ content. ${ }^{13)}$ For the pure $\mathrm{ZnO}$ film, optical transmittance in the visible range was about $80 \%$ and the exhibited absorption edge approached $362 \mathrm{~nm}$. Table 1 presents the transmittance levels at a wavelength of $550 \mathrm{~nm}$; $\mathrm{Mg}$ incorporated samples show higher transparency levels than the pure $\mathrm{ZnO}$ sample. However, the transmittance was lower for higher $\mathrm{Mg}$ content samples, with $x \geq 0.3$, than for the $x=0.2$ sample. This result is in good agreement with the results of XRD, SEM and SPM and relates to $\mathrm{MgO}$ phase segregation. In this study, the $\mathrm{Zn}_{0.8} \mathrm{Mg}_{0.2} \mathrm{O}$ sample exhibited $94.7 \%$ transparency, which was the best transparency among incorporated samples and gave an increase of about $13.5 \%$ over the pure $\mathrm{ZnO}$ sample.

In direct bandgap semiconductors, the absorption edge can be analyzed by the relation; ${ }^{29)}$

$$
\alpha(h v)=A\left(h v-E_{g}\right)^{1 / 2},
$$

where $\alpha$ is the absorption coefficient, $h v$ is the photon energy, $A$ is a constant and $E_{g}$ is the optical bandgap. The absorption coefficient $(\alpha)$ in the UV region of these $\mathrm{Zn}_{1-x} \mathrm{Mg}_{x} \mathrm{O}$ thin films can be calculated from $\left.I=I_{o} e^{-\alpha t},{ }^{30}\right)$ where $I$ is intensity of the transmitted light, $I_{o}$ is the intensity of incident light and $t$ is the thickness of the $\mathrm{Zn}_{1-x} \mathrm{Mg}_{x} \mathrm{O}$ films. Figure $5(\mathrm{~b})$ is the plot of $(\alpha h v)^{2}$ vs. photon energy. These curves are evaluated from the transmittance spectra in Fig. 5(a). Extrapolation methods can determine the optical bandgaps of $\mathrm{Zn}_{1-x} \mathrm{Mg}_{x} \mathrm{O}$ thin films. The optical bandgap values $\left(E_{g}\right)$ listed in Table 1 show the bandgap increased with $\mathrm{Mg}$ content, from $3.24 \mathrm{eV}$ to $3.52 \mathrm{eV}$, for $0 \leq x \leq 0.3$. Cohen et al. ${ }^{20)}$ have indicated that $E_{g}$ values of $\mathrm{Zn}_{1-x} \overline{M g}_{x} \mathrm{O}$ increases further to $3.64 \mathrm{eV}$ due to the Burstein-Moss shift. ${ }^{31)}$ In films with $x$ values exceeding 0.3 the $E_{g}$ approaches $3.47 \mathrm{eV}$. It is possible that second phase segregation caused this effect.

$\mathrm{ZnO}$ exhibits wide-range conductivity; its behavior ranges from metallic to insulating. Its electrical characteristics can be controlled by doping with ternary elements or adjusted process conditions. Table 1 shows the resistivity values of $\mathrm{Zn}_{1-x} \mathrm{Mg}_{x} \mathrm{O}$ thin films with various $\mathrm{Mg}$ content. The resistivities of $\mathrm{ZnO}$ films increased one or two orders of magnitude when $\mathrm{Mg}$ was incorporated and the $\mathrm{Zn}_{0.8} \mathrm{Mg}_{0.2} \mathrm{O}$ sample exhibited the highest resistivity among incorporated samples, $8.3 \times 10^{5} \Omega$-cm. Liu et al. ${ }^{32)}$ have reported that when $\mathrm{Mg}$ is doped into $\mathrm{ZnO}$, interstitial metal atom and oxygen vacancies can be depressed. A Mg-doped $\mathrm{ZnO}$ film's appearance increases its resistivity.

An $\mathrm{MgO}$ formation as a secondary phase above the solubility limit of $\mathrm{Zn}_{1-x} \mathrm{Mg}_{x} \mathrm{O}$ phase can cause degeneration of crystallinity, electrical and optical properties. The present research suggests that, in order to make sure the $\mathrm{Zn}_{1-x} \mathrm{Mg}_{x} \mathrm{O}$ film possesses pure hexagonal crystal structure, the $\mathrm{Mg}^{2+}$ content should not be greater than $x=0.3$. A single-phase, defect-free polycrystalline semiconductor thin film with uniform thickness and a flat surface can serve as an active channel layer for carrier propagation from source to drain 


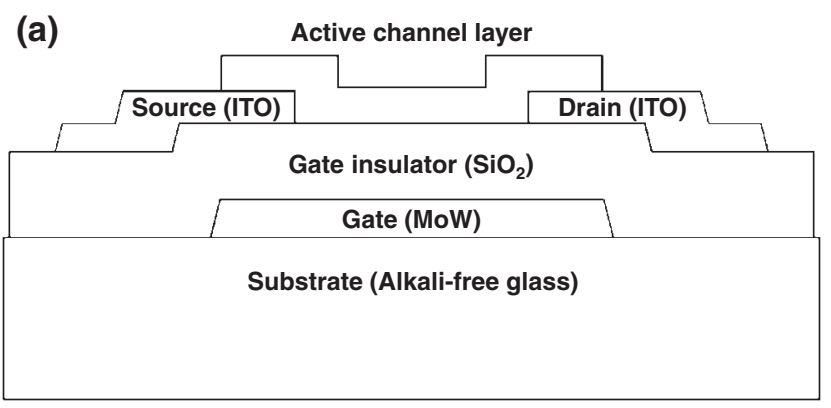

(b)

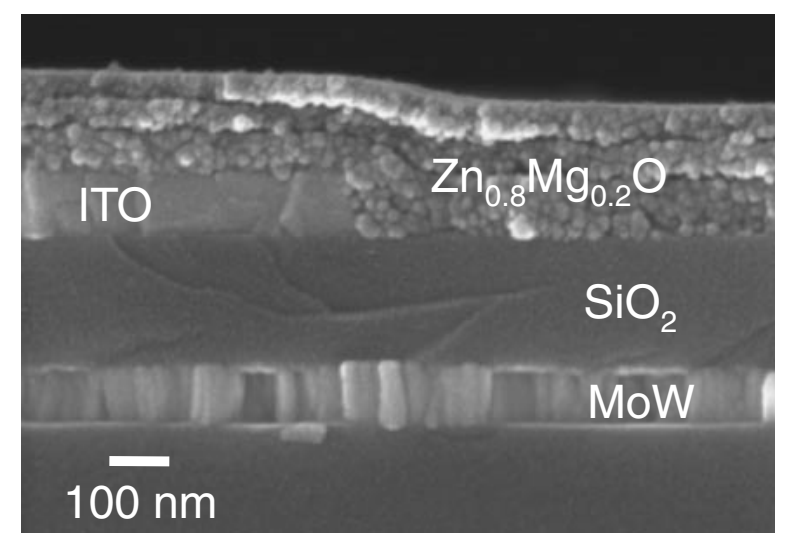

Fig. 6 (a) Schematic diagram of $\mathrm{Zn}_{1-x} \mathrm{Mg}_{x} \mathrm{O}$ TFT and (b) local crosssectional view of TFT with $\mathrm{Zn}_{0.8} \mathrm{Mg}_{0.2} \mathrm{O}$ active channel layer.

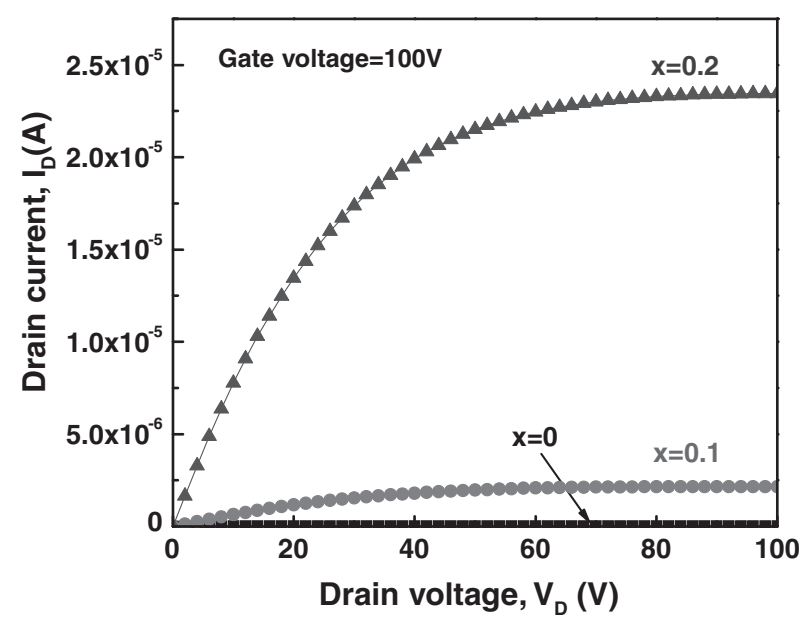

Fig. $7 I_{D^{-}} V_{D}$ curves of $\mathrm{Zn}_{1-x} \mathrm{Mg}_{x} \mathrm{O}$ TFTs with various $\mathrm{Mg}$ content.

(Fig. 6(a)). Figure 6(b) shows a local cross-section view of a $\mathrm{Zn}_{0.8} \mathrm{Mg}_{0.2} \mathrm{O}$ TFT. The image shows that the $\mathrm{Zn}_{0.8} \mathrm{Mg}_{0.2} \mathrm{O}$, film was successfully deposited on a multilayer device and did not cause defects on interfaces between ITO/ $\mathrm{Zn}_{0.8} \mathrm{Mg}_{0.2} \mathrm{O}$ or $\mathrm{SiO}_{2} / \mathrm{Zn}_{0.8} \mathrm{Mg}_{0.2} \mathrm{O}$.

Figure 7 shows the drain current-drain voltage $\left(I_{D}-V_{D}\right)$ characteristics of $\mathrm{Zn}_{1-x} \mathrm{Mg}_{x} \mathrm{O}$ TFTs. It shows that these field effect transistors operated in an n-type enhancement mode and the drain current increases with positive gate bias. Further, the slope of each $I_{D}$ curve is flat and exhibits a hard saturation for large $V_{D}$ region. Hoffaman et al. ${ }^{33)}$ have indicated that hard saturation can deplete the entire layer of the $\mathrm{ZnO}$-based active channel of free electrons and that large output impedance is desirable for most circuit applications. The field-effect mobility of TFT devices depend on the saturated current. Therefore, the $\mathrm{Zn}_{0.8} \mathrm{Mg}_{0.2} \mathrm{O}$ TFTs exhibit the best performance among our samples, according to $I_{D}-V_{D}$ characteristics.

\section{Conclusions}

Magnesium substituted zinc oxide thin films have been prepared successfully by solution-based process that combined a sol-gel method and a spin-coating technique. The heat-treated films that have less than $0.3 \mathrm{Mg}$ addition exhibits wurzite phase; those films with higher $\mathrm{Mg}$ levels $(x \geq 0.3)$ show segregation of $\mathrm{MgO}$ and degrade film quality. The additions of $\mathrm{Mg}$ into $\mathrm{ZnO}$ thin films not only refine the grain size but also increase the transmittance of thin films. Among the $\mathrm{Zn}_{1-x} \mathrm{Mg}_{x} \mathrm{O}(0 \leq x \leq 0.36)$ films investigated in the present study, the $\mathrm{Zn}_{0.8} \mathrm{Mg}_{0.2} \mathrm{O}$ film exhibits the best transparency and the highest resistivity. Its average crystallite size is $8.7 \mathrm{~nm}$ with its transparency and resistivity of $94.7 \%$ and $8.3 \times 10^{5} \Omega$-cm, respectively.

\section{Acknowledgments}

The authors gratefully acknowledge the financial support by the National Science Council of Republic of China under Contract No. NSC 95-2221-E-035-006 and Taiwan TFTLCD Association (TTLA) under Contract No. A643TT1000S11.

\section{REFERENCES}

1) H. Ohta and H. Hosono: Materials Today 7 (2004) 42-51.

2) J. F. Wager: Science. 300 (2003) 1245-1246.

3) A. N. Banerjee, C. K. Ghosh, K. K. Chattopadhyay, H. Minoura, A. K. Sarkar, A. Akiba, A. Kamiya and T. Endo: Thin Solid Films. 496 (2006) 112-116.

4) W. Li, Y. Sun, Y. Wang, H. Cai, F. Liu and Q. He: Solar Energy Mater. Solar Cells. 91 (2007) 659-663.

5) B. Y. Oh, M. C. Jeong and J. M. Myoung: Appl. Surf. Sci. 253 (2007) 7157-7161.

6) R. B. M. Cross and M. M. De Souza: Appl. Phys. Lett. 89 (2006) 263513.

7) D. P. Norton, Y. W. Heo, M. P. Ivill, K. Ip, S. J. Pearton, M. F. Chisholm and T. Steiner: Materials Today 7 (2004) 34-40.

8) F. Oba, T. Yamamoto, Y. Ikuhara, I. Tanaka and H. Adachi: Mater. Trans. 43 (2002) 1439-1443.

9) T. W. Fang, S. C. Chiang, B. C. Chuang, C. H. Tsai, C. Y. Huang, C. C. Hsu, W. C. Lin, S. H. Lai and S. Y. Meng: Proceedings of International Display Manufacturing Conference (IDMC'07). (2007) pp. 585-587.

10) T. Hashimoto and T. Yoko: Mater. Trans. JIM 37 (1996) 435-441.

11) L. Shen, D. Xiao, P. Yu, J. Zhu, D. Gao, G. Yu and W. Zhang: Mater. Trans. 44 (2003) 1324-1327.

12) B. J. Norris, J. Anderson, J. F. Wager and D. A. Keszler: J. Phys. D: Appl. Phys. 36 (2003) L105-L107.

13) E. Fortunato, P. Barquinha, A. Pimentel, A. Goncalves, A. Marques, L. Pereira and R. Martins: Thin Solid Films. 487 (2005) 205-211.

14) J. H. Lee, P. Lin, C. C. Lee, J. C. Ho and Y. W. Wang: Jpn. J. Appl. Phys. 44 (2005) 4784-4789.

15) Y. J. Chang, D. H. Lee, G. S. Herman and C. H. Chang: Electrochem. Solid-State Lett. 10 (2007) H135-H138.

16) Y. Kwon, Y. Li, Y. W. Heo, M. Jones, P. H. Hollyway, D. P. Norton, Z. V. Park and S. Li: Appl. Phys. Lett. 84 (2004) 2685-2687.

17) W. I. Park, G. C. Yi and H. M. Jang: Appl. Phys. Lett. 79 (2001) 
2022-2024.

18) J. W. Kim, H. S. Kang, J. H. Kim, S. Y. Lee, J. K. Lee and M. Nastasi: J. Appl. Phys. 100 (2006) 033701.

19) Y. Ogawa and S. Fujihara: Phys. Stat. Sol. (a). 202 (2005) 1825-1828.

20) D. J. Cohen, K. C. Ruthe and S. A. Barnett: J. Appl. Phys. 96 (2004) 459-467.

21) T. Maemoto, N. Ichiba, S. Sasa and M. Inoue: Thin Solid Films. 486 (2005) 174-177.

22) Dhananjay and S. B. Krupanidhi: Appl. Phys. Lett. 89 (2006) 082905.

23) D. Zhao, Y. Liu, D. Shen, Y. Lu, J. Zhang and X. Fan: J. Crystal Growth. 234 (2002) 427-430.

24) C. S. Suchand Sandeep, R. Philip, R. Satheeshkumar and V. Kumar: Appl. Phys. Lett. 89 (2006) 063102.

25) B. D. Cullity and S. R. Stock: Elements of X-ray Diffraction, (PrenticeHall, Inc, New Jersey, 2001) pp. 388
26) A. Ohtomo, M. Kawasaki, T. Koida, K. Masubuchi, H. Koinuma, Y. Sakurai, Y. Yoshida, T. Yasuda and Y. Segawa: Appl. Phys. Lett. 72 (1998) 2466-2468.

27) M. Ghosh and A. K. Raychaudhuri: J. Appl. Phys. 100 (2006) 034315.

28) G. W. Scherer: J. Sol-Gel Sci. Tech. 8 (1997) 353-363.

29) K. H. Kim, K. C. Park and D. Y. Ma: J. Appl. Phys. 81 (1997) 7764-7772.

30) R. D. Tarey and T. A. Raju: Thin Solid Films. 128 (1985) 181-189.

31) A. Sarkar, S. Ghosh, S. Chaudhuri and A. K. Pal: Thin Solid Films. 204 (1991) 255-264.

32) J. Liu, W. Weng, W. Ding, K. Cheng, P. Du, G. Shen and G. Kan: Surf. Coat. Technol. 198 (2005) 274-277.

33) R. L. Hoffman, B. J. Norris and J. F. Wager: Appl. Phys. Lett. 82 (2003) $733-735$. 